\begin{tabular}{|c|c|c|c|c|c|c|}
\hline \multirow{4}{*}{ Impact Factor: } & ISRA (India) & $=3.117$ & SIS (USA) & $=0.912$ & ICV (Poland) & $=6.630$ \\
\hline & ISI (Dubai, UAE & $=0.829$ & РИНЦ (Russia & $=0.156$ & PIF (India) & $=1.940$ \\
\hline & GIF (Australia) & $=0.564$ & ESJI (KZ) & $=8.716$ & IBI (India) & $=4.260$ \\
\hline & JIF & $=1.500$ & SJIF (Morocco & $=5.667$ & OAJI (USA) & $=0.350$ \\
\hline
\end{tabular}

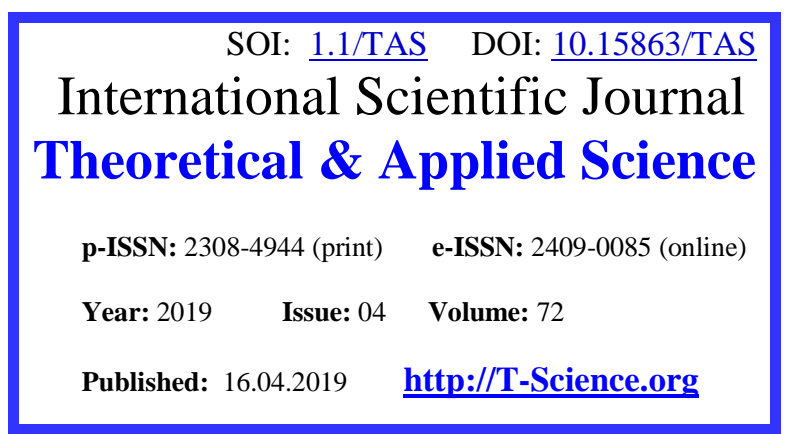

SECTION 20. Medicine.

UDC: 616-36.001-07:577.15
QR - Issue

QR - Article
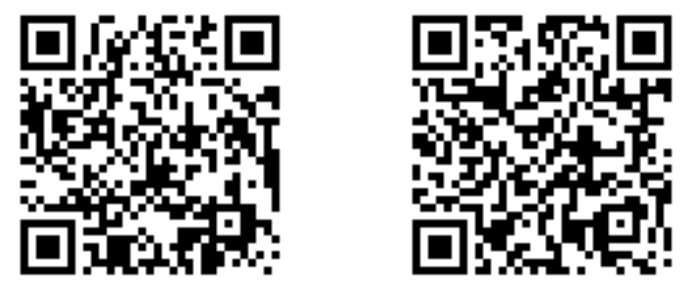

Mirhalil Dzhalilovich Akhmedov Assistant of the Department of General Surgery,

Tashkent Pediatric Medical Institute

\begin{abstract}
Tahir Askarovich Askarov
Doctor of Medical Sciences,

Professor, Head of the Department of General Surgery,

Tashkent Pediatric Medical Institute

Yokub Nishanovich Fayziev

Candidate of Medical Sciences,

Associate Professor of the Department of General

Surgery, Tashkent Pediatric Medical Institute
\end{abstract}

Ahmadjon Makhamadjonovich Ashurmetov

Candidate of Medical Sciences,

Assistant of the Department of General Surgery,

Tashkent Pediatric Medical Institute

Farhod Mirjalilovich Ismailov

Assistant of the Department of General Surgery,

Tashkent Pediatric Medical Institute

Malika Satarovna Begmanova

4th year student direction medical business

Tashkent Pediatric Medical Institute

\title{
THE MITOCHONDRIAL ENZYME ACTIVITY IN THE EVALUTION OF HEPATOCELLULAR INJURIES
}

Abstract: The test of quantitative evalution of the state of liver parenchyma has been developed on the basis of different models of hepatocelluiar injuries induced by effect of CCL4, DL-galactosamine, mechanical jaundice, ischemia in the laboratory animals. The test was based on determination of the coefficient obtained due to studying of the activity of cytochromoxidase during the, presense of two substrates cytochrome C and TMFD in the organ tissue homogenate.

Key words: mitochondria, enzymes, hepatocellular damage, jaundice, animals, carbon tetrachloride.

Language: English

Citation: Akhmedov, M. D., Askarov, T. A., Fayziev, Y. N., Ashurmetov, A. M., Ismailov, F. M., \& Begmanova, M. S. (2019). The mitochondrial enzyme activity in the evalution of hepatocellular injuries. ISJ Theoretical \& Applied Science, 04 (72), 181-187.

Soi: http://s-o-i.org/1.1/TAS-04-72-24 Doi: crossef https://dx.doi.org/10.15863/TAS.2019.04.72.24

Topicality.

Currently, methods for diagnosing acute and chronic liver diseases are known, based on determining the activity of various enzymes in the blood and liver tissue, the rate of absorption of dyes and radioactive substances, according to the level of metabolites synthesized by this organ $[2,4,5,8,9]$.
However, none of these diagnostic tests gives an idea of the number of safe and functionally capable cells of the liver parenchyma, but allows only forming a qualitative understanding of the pathological process in this organ.

At the same time, such diagnostic test is necessary in hepatology, it would allow to objectively 


\begin{tabular}{|c|c|c|c|c|c|c|}
\hline \multirow{4}{*}{ Impact Factor: } & ISRA (India) & $=3.117$ & SIS (USA) & $=0.912$ & ICV (Poland) & $=6.630$ \\
\hline & ISI (Dubai, UAE & $=0.829$ & РИНЦ (Russia & $=\mathbf{0 . 1 5 6}$ & PIF (India) & $=1.940$ \\
\hline & GIF (Australia) & $=0.564$ & ESJI (KZ) & $=8.716$ & IBI (India) & $=4.260$ \\
\hline & JIF & $=1.500$ & SJIF (Morocco & $=5.667$ & OAJI (USA) & $=0.350$ \\
\hline
\end{tabular}

represent the state of the hepatic parenchyma in each specific case $[1,3]$, to approach the choice of treatment method reasonably and the extent of surgical intervention, its pathogenetic validity and an adequate postoperative course [6].

\section{Material and research methods.}

To solve the set task, acute and chronic experiments were performed on 200 male rats weighing 160-180 grams, on 46 dogs of different weights and sexes. In addition, 24 patients with diseases of the hepatobiliary zone were examined.

Having chosen the study of the mitochondrial respiratory chain responsible for the energy of the liver cell and consuming $90 \%$ of the oxygen entering the cell, as the main part of researchwork, we investigated the activity of cytochrome oxidase (cytochrome $a+a 3$ ). The latter was studied by us in the presence of two substrates: cytochrome with natural electron donor and tetramethyl-paraphenylenediamine (TMPD) -artificial electron donor. The need for such a method is due to the fact that the reduced cytochrome $\mathrm{C}$ transfers electrons to the cytochrome oxidase oligofermentation complex, which activates oxygen to form $\mathrm{OH}-$ through cytochrome a3. Restored TMPD is oxidized through cytochromes a $+\mathrm{a} 3$, localized on the inner mitochondrial membrane (Jacob E / E., 1960).

To measure cytochrome oxidase activity in the presence of TMPD and cytochrome C, a piece of organ was taken and a homogenate was prepared in a Downes homogenizer in a medium consisting of 0.25

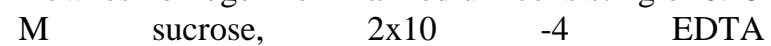

(Ethylendiaminetetraacetatu), $0.01 \mathrm{M}$ tris- $\mathrm{HCl}$ buffer ( $\mathrm{pH}-7.6-7.8)$. The ratio of liver tissue and medium was 1: 2 weight / volume. Polarographic analysis on LP-7 (Czech Republic) was performed with a standard Clark platinum electrode of the closed type.

The resulting homogenate was added to a polarographic cell with a volume of $1.1 \mathrm{ml}(\mathrm{t}=37 \mathrm{C})$ at a rate of $1.4 \mathrm{mg}$. protein on a given volume of the cuvette. After that, the rate of oxygen consumption was recorded. Similar recordings were carried out with sequential addition of sodium ascorbate to the paleographic cell - a final concentration of $2 \mathrm{~mm}$. TMPD and cytochrome $\mathrm{C}$ at a final concentration of 1 $\mu \mathrm{m}$ and $5 \mu \mathrm{m}$, respectively.

Cytochrome $\mathrm{C}$ and TMPD oxidase activities were on per $1 \mathrm{mg}$ of protein minus ascorbate dependent oxygen consumption.

\section{Results and discussion.}

Toxic liver damage was caused in rats by administering DL-galactosamine and carbon tetrachloride. The inoculation of rats with galactosamine at a dose of $150 \mathrm{mg} . / 100$ gr. resulted in the death of all animals after 56 hours of observation. Moreover, two thirds of them died in the first two days. In animals, the clinical picture of acute liver failure is increasing. By this period of observation, they become adynamic, the wool is disheveled, the animals do not drink water, and the reaction to the pain stimulus is reduced and slowed down. After 48 hours of inoculation, the liver of animals has a clay color, flabby, gives abundant scraping.

Table 1. Activity TMPD-and cytochrome-C-oxidase (in nmol $02 \mathrm{~min}-1 \mathrm{mg}-1$ ) in the liver of gnawers, inoculated with galactosamine.

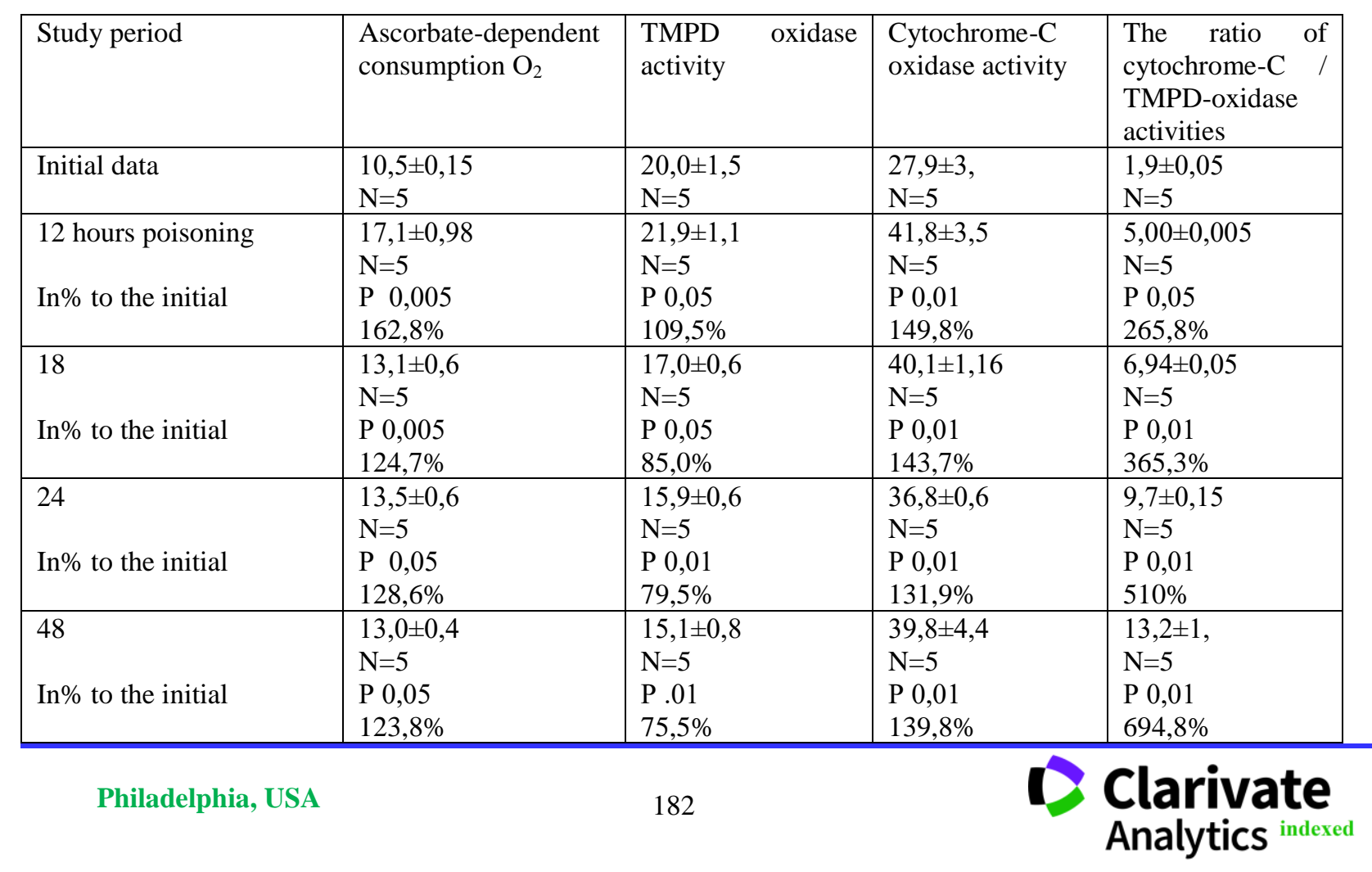




\begin{tabular}{|c|c|c|c|c|c|c|}
\hline \multirow{4}{*}{ Impact Factor: } & ISRA (India) & $=3.117$ & SIS (USA) & $=0.912$ & ICV (Poland) & $=6.630$ \\
\hline & ISI (Dubai, UAE & $=0.829$ & РИНЦ (Russia & $=\mathbf{0 . 1 5 6}$ & PIF (India) & $=1.940$ \\
\hline & GIF (Australia) & $=0.564$ & ESJI (KZ) & $=8.716$ & IBI (India) & $=4.260$ \\
\hline & JIF & $=1.500$ & SJIF (Morocco & $=5.667$ & OAJI (USA) & $=0.350$ \\
\hline
\end{tabular}

According to the data presented in table No. 1, TMPD-oxidase activity by 12 hours of observation practically retains the same level as in an intact liver. However, the activity of cytochrome-C-oxidase statistically significantly increased by 1.5 times. The coefficient or ratio of these activities reaches $5.0 \pm$ 0.05 units. Such dynamics suggest that by 12 hours there are some changes in the respiratory chain of mitochondrial electron transport. They can be associated with both terminal mitochondrial oxidase and the respiratory complex oxidized by TMPD. The latter assumption is more likely because the addition of exogenous cytochrome $C$, i.e. reconstruction of the respiratory chain leads to an increase in the circulation of the cycles in the mitochondrial electron transport complexes of the respiratory enzymes of mitochondria. The increase in TMPD-oxidase activity is a reflection of some changes occurring with endogenous cytochrome-C. After 18 hours of the seed of DL-galactosamine, the activity of TMPD oxidase starts to fall statistically in significant way. And in subsequent observation periods ( 24 and 48 hours), this decrease reaches the highest values $(24.5 \%)$ compared with the control data. During these same periods of the study an increased level of cytochrome $\mathrm{C}$-oxidase is maintained. And compared with intact animals, this increase ranges from $31.9-43.7 \%$.

Consequently, in rats with such duration of priming with galactosamine, after 18 hours of research, it can be considered threshold, although oxygen consumption increases with the addition of exogenous cytochrome- $\mathrm{C}$ by almost the same amount. TMPD oxidase activity decreases not only due to changes in the cytochrome-C respiratory chain, but also degradation of cytochrome $\mathrm{a}+\mathrm{a} 3$.

Table 2. Shows the results of experiments in gnawers inoculated by carbon tetrachloride.

\begin{tabular}{|l|l|l|l|l|}
\hline Study period & $\begin{array}{l}\text { Ascorbate- } \\
\text { dependent } \\
\text { consumption } \mathrm{O}_{2}\end{array}$ & $\begin{array}{l}\text { TMPD oxidase } \\
\text { activity }\end{array}$ & $\begin{array}{l}\text { Cytochrome-C } \\
\text { oxidase activity }\end{array}$ & $\begin{array}{l}\text { The ratio of } \\
\text { cytochrome-C / } \\
\text { TMPD-oxidase } \\
\text { activities }\end{array}$ \\
\hline Initial data & $10,5 \pm 0,15$ & $20,0 \pm 1,5$ & $27,9 \pm 3,0$ & $1,9 \pm 0,05$ \\
$\mathrm{~N}=5$ & $\mathrm{~N}=5$ & $\mathrm{~N}=5$ & $\mathrm{~N}=5$ \\
\hline 12 hours poisoning & $13,7 \pm 0,36$ & $21,9 \pm 0,4$ & $73,2 \pm 3$ & $7,2 \pm 0,05$ \\
& $\mathrm{~N}=5$ & $\mathrm{~N}=5$ & $\mathrm{~N}=5$ & $\mathrm{~N}=5$ \\
in \% to the initial. & $\mathrm{P} 0,01$ & $\mathrm{P} 0,05$ & $\mathrm{P} 0,01$ & $\mathrm{P} 0,01$ \\
& $130,5 \%$ & $109,5 \%$ & $262,4 \%, 0$ & $378,9 \%$ \\
\hline 24 hours poisoning & $11,8 \pm 0,4$ & $14,8 \pm 0,4$ & $65,9 \pm 2,0$ & $10,9 \pm 0,4$ \\
& $\mathrm{~N}=5$ & $\mathrm{~N}=5$ & $\mathrm{~N}=5$ & $\mathrm{~N}=5$ \\
in \% to the initial. & $\mathrm{P} 0,01$ & $\mathrm{P} 0,01$ & $\mathrm{P} 0,01$ & $\mathrm{P} 0,01$ \\
& $112,4 \%$ & $74,0 \%$ & $236,2 \%$ & $573,7 \%$ \\
\hline
\end{tabular}

They indicate that the 12 hours of study TMPD oxidase activity was not significantly changed. By 24 hours after poisoning, this drop is significant and amounts to $26 \%$ of the initial level. In this group of experiments, as in experiments with DLgalactosamine, a similar dynamics takes place. Only in cases of poisoning with carbon tetrachloride in a dose of $0.25 \mathrm{ml} . / 100 \mathrm{gr}$. Of weights, the critical moment is shifted to 12 hours of study.

By this period, cytochrome-C-oxidase activity increases for 2.6 times and the degree of almost the same increase (2.4 times) persists up to 24 hours after poisoning. Although we have unidirectional intensification of oxygen consumption when exogenous cytochrome-C is added when administered to animals galactosamine and carbon tetrachloride, their intensity is different. The reason for this difference requires additional research and, perhaps, is determined by the specifics of their action. This apparently important fact is that the hepatocyte plasma membranes are to a greater degree the action of galactosamine.

This leads to more rapid degradation of the respiratory chain carrier structured in the inner membrane of mitochondria, exogenous cytochrome $\mathrm{C}$, and possibly cytochrome a $+\mathrm{a} 3$. Probably, damage to mitochondrial membranes is most pronounced when poisoning with galactosamine. Although under conditions of damage by carbon tetrachloride, it is possible to expect an increase in the role of free oxidation, i.e. reactions competing for oxygen.

At a later stage of poisoning with $\mathrm{CCl}_{4}$, when structural disorders of hepatocytes are seen clearly, and its mitochondria, respectively, is clearly expressed, the activity of cytochrome-C-oxidase falls almost to the level that animals have, starting from the 12-hour study period after poisoning with galactosamine So, after 36 hours and 48 hours after the administrating $\mathrm{CCl}_{4}$, the activity of cytochrome C-oxidase is $48.8 \pm 1.3$ and $46.7 \pm 1.1 \mathrm{nmol}$, respectively, \pm 0.25 and $17.4 \pm 0.3 \mathrm{nmol} . \mathrm{O}_{2} / \mathrm{min} .-1$ 


\begin{tabular}{|c|c|c|c|c|c|c|}
\hline \multirow{4}{*}{ Impact Factor: } & ISRA (India) & $=3.117$ & SIS (USA) & $=0.912$ & ICV (Poland) & $=6.630$ \\
\hline & ISI (Dubai, UAE & $=0.829$ & РИНЦ (Russia & $=\mathbf{0 . 1 5 6}$ & PIF (India) & $=1.940$ \\
\hline & GIF (Australia) & $=0.564$ & ESJI (KZ) & $=8.716$ & IBI (India) & $=4.260$ \\
\hline & JIF & $=1.500$ & SJIF (Morocco & $=5.667$ & OAJI (USA) & $=0.350$ \\
\hline
\end{tabular}

mg.-1 protein. And the level of the latter was not statistically significantly different from that of the animals inoculated with galactosamine for 18-48 hours (p 0.005, $\mathrm{n}=5$ ).
In an effort to use a cleaner model of liver parenchyma damage, we used ischemia.

Table 3. Activity of TMPD-and cytochrome-C-oxidase in ischemic liver of gnawers.

\begin{tabular}{|c|c|c|c|c|}
\hline Study period & $\begin{array}{ll}\text { Ascorbate- } & \\
\text { dependent } & \mathrm{O}_{2} \\
\text { Consumption } & \end{array}$ & $\begin{array}{l}\text { TMPD } \\
\text { activity }\end{array}$ & $\begin{array}{l}\text { Cytochrome-C- } \\
\text { ocidase activity }\end{array}$ & $\begin{array}{l}\text { The ratio of cytochrome- } \\
\text { C / TMP- } \\
\text { oxide.activities }\end{array}$ \\
\hline Initial data & $\begin{array}{l}10,5 \pm 0,15 \\
\mathrm{~N}=5\end{array}$ & $\begin{array}{l}20,0 \pm 1,5 \\
\mathrm{~N}=5\end{array}$ & $\begin{array}{l}27,9 \pm 3,0 \\
\mathrm{~N}=5\end{array}$ & $\begin{array}{l}1,9 \pm 0,05 \\
\mathrm{~N}=5\end{array}$ \\
\hline $\begin{array}{l}30 \text { minutes } \\
\text { Ischemia } \\
\text { In } \% \text { to the initial }\end{array}$ & $\begin{array}{l}10,5 \pm 0,26 \\
\mathrm{~N}=5 \\
\mathrm{P} 0,05 \\
100,0 \%\end{array}$ & $\begin{array}{l}16,5 \pm 0,45 \\
\mathrm{~N}=5 \\
\mathrm{P} 0,01 \\
82,5 \%\end{array}$ & $\begin{array}{l}28,6 \pm 0,86 \\
N=5 \\
P 0,05 \\
102,5 \%\end{array}$ & $\begin{array}{l}3,0 \\
\mathrm{~N}=5 \\
\mathrm{P} 0,01 \\
157,9 \%\end{array}$ \\
\hline $\begin{array}{l}60 \text { minutes } \\
\text { Ischemia } \\
\text { In } \% \text { to the initial }\end{array}$ & $\begin{array}{l}12,0 \pm 0,8 \\
\mathrm{~N}=5 \\
\text { P } 0,05 \\
114,3 \%\end{array}$ & $\begin{array}{l}15,7 \pm 0,9 \\
\mathrm{~N}=5 \\
\text { P 0,01 } \\
78,5 \%\end{array}$ & $\begin{array}{l}33,8 \pm 2,6 \\
N=5 \\
\text { P 0,05 } \\
121,0 \%\end{array}$ & $\begin{array}{l}5,9 \pm 0,06 \\
\mathrm{~N}=5 \\
\mathrm{P} 0,01 \\
310,5 \%\end{array}$ \\
\hline $\begin{array}{l}120 \text { minutes } \\
\text { Ischemia } \\
\text { In } \% \text { to the initial }\end{array}$ & $\begin{array}{l}11,2 \pm 0,36 \\
\mathrm{~N}=5 \\
\mathrm{P} 0,05 \\
106,7 \%\end{array}$ & $\begin{array}{l}15,9 \pm 0,9 \\
\mathrm{~N}=5 \\
\mathrm{P} 0,01 \\
79,5 \%\end{array}$ & $\begin{array}{l}49,7 \pm 6.3 \\
N=5 \\
\text { P 0,01 } \\
178,1 \%\end{array}$ & $\begin{array}{l}.8,1 \pm 0,07 \\
\mathrm{~N}=5 \\
\text { P } 0,01 \\
426,4 \%\end{array}$ \\
\hline
\end{tabular}

As follows from table 3, the deprivation of the liver by oxygen under the conditions of normothermia almost did not lead to a change in ascorbate dependent oxygen consumption. TMPD-oxidase activity decreases most significantly by 60 minutes of ischemia (by 21.5\%) and remains practically the same after 120 minutes of research. Its level, starting from 60 minutes, increases by 1.2 times and continues to increase by 120 minutes of ischemia. After 180 minutes of liver deprivation of blood flow, cytochrome-C-oxidase activity increases by 2.4 times (reaches $67.3 \pm 2.8 \mathrm{nmol} \mathrm{O}_{2} /$ min-1 protein $(\mathrm{p} 0.01, \mathrm{n}$ $=5$ ).

Interesting data was obtained by us in the group of experiments with obstructive jaundice. Ligation of the common bile duct led to the fact that after 7 days the activity of cytochrome oxidase increased with the addition of substrates: TMPD and cytochrome $\mathrm{C}$.

If TMPD oxidase activity increased only by 1.4 times, then cytochrome-C-oxidase activity increased significantly (3.1 times). The increased level of the latter persists with obstructive jaundice lasting for 14 and 21 days. During these periods of the study, there is a higher activity of TMPD-ok Sidazy. It is 2.4 times more than intact animals and 1.7 times higher than rats with obstructive jaundice lasting for 7 days.

In this group of experiments, as in the previous ones, it turned out that 7 days turned out to be a critical period. And indeed, the icterus of the paws and auricles, the reduced reaction to painful stimuli, disheveled hair, and nodule secretions occurred. At necropsy of animals, hemorrhage was noted in the mesentery, pleural cavity. Their livers were of lemonyellow color and soft consistency.

Summarizing the data obtained by us in the process of modeling various pathological processes in the liver, it should be noted that the absolute values of the activities of terminal mitochondrial oxidase are subject to considerable fluctuations. The scope of the latter is not controllable, because, like the activity of other enzymes, the mitochondrial respiratory chain complexes are susceptible to genetic, hormonal and other known types of control. Because of this, it would be a methodological mistake to recommend and use in practical hepatology we studied the levels of cytochrome oxidase activity, determined using TMPD and cytochrome $\mathrm{C}$, in assessing the degree of damage to the liver parenchyma under various pathological conditions.

The assumption that changes in the activity of the cytochrome oxidase complex when used as a substrate for TMPD is due to damage to the mitochondrial membranes and changes that occur with such a respiratory carrier as cytochrome $\mathrm{C}$. by solubilizing and exiting the hepatocyte from the inner mitochondrial membrane to the matrix. And indeed adding exogenous cytochrome-C substantially restores cytochrome activity. The present fact was the basis for the assumption that the ratio of cytochrome $\mathrm{C}$ and TMPD oxidase activity will serve as an indicator of the degree of damage to mitochondrial membranes and degradation localized in the inner membrane of the respiratory carriers' subcellular structures. 


\begin{tabular}{|c|c|c|c|c|c|c|}
\hline \multirow{4}{*}{ Impact Factor: } & ISRA (India) & $=3.117$ & SIS (USA) & $=0.912$ & ICV (Poland) & $=6.630$ \\
\hline & ISI (Dubai, UAE & $=0.829$ & РИНЦ (Russia & $=\mathbf{0 . 1 5 6}$ & PIF (India) & $=1.940$ \\
\hline & GIF (Australia) & $=0.564$ & ESJI (KZ) & $=8.716$ & IBI (India) & $=4.260$ \\
\hline & JIF & $=1.500$ & SJIF (Morocco & $=5.667$ & OAJI (USA) & $=0.350$ \\
\hline
\end{tabular}

The calculation of this ratio or coefficient showed when an animal is being inoculated with Dgalactosamine, its numerical value increases during all periods of the study (Table 1). A particularly intensive increase in the coefficient occurs during the first 18-24 hours. During this observation period, it is 3.6-5.1 times higher than the data available in the intact liver and reaches 6.9-9.7 units. After 24 hours, the death of the experimental animals begins. By the 48 hours of the study, 10 rats died out of 23 rats, i.e. almost half. The values of the coefficient continue to increase, although less intensively, and by 48 hours they reach $13.2 \pm 1.0$ units. And in parallel, all animals died by 56 hours priming with galactosamine (LD = 100).

Practically the same angle of inclination has a graphical curve of the coefficient values within the first 24 hours after the seed $\mathrm{CCl}_{4}$, by 36 and 48 hours of the study, it reaches $7.1 \pm 0.04$ and $6.0 \pm 0.04$ units, respectively. It turned out that by 24 hours half of the animals died (23 out of 48 rats). The remaining animals, whose coefficient was 6 units, survived and stayed alive for a long time after the seed of $\mathrm{CCl}_{4}$.

A similar pattern is observed in animals with obstructive jaundice.

Table 4. Activity of TMPD-and cytochrome-C-oxidase homogenates of the liver of gnawers with obstructive jaundice.

\begin{tabular}{|c|c|c|c|c|}
\hline Study period & $\begin{array}{l}\text { Ascorbate- } \\
\text { dependent } \mathrm{O} 2 \\
\text { Consumption }\end{array}$ & $\begin{array}{l}\text { TMPD } \quad \text { oxidase } \\
\text { activity }\end{array}$ & $\begin{array}{l}\text { Cytochrome-C- } \\
\text { ocidase activity }\end{array}$ & $\begin{array}{l}\text { The ratio of } \\
\text { cytochrome-C / } \\
\text { TMPD- } \\
\text { oxide.activities }\end{array}$ \\
\hline Initial data & $\begin{array}{l}10,5 \pm 0,15 \\
\mathrm{~N}=5\end{array}$ & $\begin{array}{l}20,0 \pm 1,5 \\
\mathrm{~N}=5\end{array}$ & $\begin{array}{l}27,9 \pm 3,0 \\
N=5\end{array}$ & $\begin{array}{l}1,9 \pm 0,05 \\
\mathrm{~N}=5\end{array}$ \\
\hline $\begin{array}{l}7 \text { days of obstructive } \\
\text { jaundice } \\
\text { In } \% \text { to the initial }\end{array}$ & $\begin{array}{l}20,8 \pm 0,8 \\
\mathrm{~N}=5 \\
\mathrm{P} 0,01 \\
198,1 \%\end{array}$ & $\begin{array}{l}27,8 \pm 0,9 \\
\mathrm{~N}=5 \\
\mathrm{P} 0,02 \\
139,0 \%\end{array}$ & $\begin{array}{l}87,9 \pm 2,5 \\
\mathrm{~N}=5 \\
\mathrm{P} 0,01 \\
315,0 \% \\
\end{array}$ & $\begin{array}{l}9,8 \pm 0,3 \\
\mathrm{~N}=5 \\
\mathrm{P} 0,01 \\
515,8 \%\end{array}$ \\
\hline $\begin{array}{l}14 \text { days of obstructive } \\
\text { jaundice } \\
\text { B \% }\end{array}$ & $\begin{array}{l}37,7 \pm 0,9 \\
\mathrm{~N}=5 \\
\mathrm{P} 0,01 \\
359,0 \%\end{array}$ & $\begin{array}{l}47,5 \pm 0,8 \\
\mathrm{~N}=5 \\
\mathrm{P} 0,01 \\
237,5 \% \\
\end{array}$ & $\begin{array}{l}95,7 \pm 0,6 \\
\mathrm{~N}=5 \\
\mathrm{P} 0,01 \\
343,0 \% \\
\end{array}$ & $\begin{array}{l}5,9+\_006 \\
\mathrm{~N}=5 \\
\mathrm{P} 0,01 \\
310,5 \%\end{array}$ \\
\hline $\begin{array}{l}21 \text { days of obstructive } \\
\text { jaundice } \\
\mathrm{B} \% \text { to the initial. }\end{array}$ & $\begin{array}{l}22,9 \pm 0,7 \\
\mathrm{~N}=5 \\
\mathrm{P} 0,01 \\
218,1 \%\end{array}$ & $\begin{array}{l}32,1 \pm 1,1 \\
\mathrm{~N}=5 \\
\mathrm{P} 0,01 \\
160,5 \%\end{array}$ & $\begin{array}{l}73,8 \pm 4,5 \\
\mathrm{~N}=5 \\
\mathrm{P} 0,01 \\
264,5 \%\end{array}$ & $\begin{array}{l}5,5 \pm 0,05 \\
\mathrm{~N}=5 \\
\mathrm{P} 0,01 \\
289,5 \%\end{array}$ \\
\hline
\end{tabular}

The same intensive growth of the coefficient is seen during the first 7 days of observation. And this period turned out to be critical, after which 22 out of 37 rats died, i.e. 59.4\%. The rest of the gnawers survived and were withdrawn from the experiment after two months. They had a factor of $5.9 \pm 0.06$ and $5.5 \pm 0.05$ units by 14 and 21 days of the study (table $4)$. at autopsy of gnawers within the specified time, recanalization of the duct and restoration of the outflow of bile from the liver was discovered [9].

The data presented above clearly indicate that those gnawers that have coefficient values above 7-8 units die. Therefore, such values allow diagnosing the hardest form of structural and functional disorders in the liver as a result of the pathological process. And the specificity of this process does not matter.
However, such an approach to diagnosing the state of the liver parenchyma did not give an idea of the quantitative characteristic of the degree of damage to the liver parenchyma biopsies of liver tissue, when one part of it was used to determine the ratio of cytochrome $\mathrm{C}$ and TMPD oxidize activities, and another, to separate cells. Viable hepatocytes were identified by staining with vital dye trypan blue, and counted in the Goryaev's camera.

According to table 5 it follows that there is an inverse relationship between the values of the coefficient and the number of viable hepatocytes. If intact gnawers have $1.9 \times 10$ grams of liver in 7 degrees of viable hepatocytes, then at a factor of 6.94 only $35 \%$ of cells remain intact. 


\begin{tabular}{|c|c|c|c|c|c|c|}
\hline \multirow{4}{*}{ Impact Factor: } & ISRA (India) & $=3.117$ & SIS (USA) & $=0.912$ & ICV (Poland) & $=6.630$ \\
\hline & ISI (Dubai, UAE & $=0.829$ & РИНЦ (Russia & $=\mathbf{0 . 1 5 6}$ & PIF (India) & $=1.940$ \\
\hline & GIF (Australia) & $=0.564$ & ESJI (KZ) & $=8.716$ & IBI (India) & $=4.260$ \\
\hline & JIF & $=1.500$ & SJIF (Morocco & $=5.667$ & OAJI (USA) & $=0.350$ \\
\hline
\end{tabular}

Table 5. Indicators of the coefficient and the number of viable hepatocytes in rats inoculated with galactosamine.

\begin{tabular}{|c|c|c|c|}
\hline № & $\begin{array}{c}\text { The ratio of cytochrome C / } \\
\text { TMPD-oxide. activities (in } \\
\text { units) }\end{array}$ & $\begin{array}{c}\text { The quantity of viable hepatocytes in gr. } \\
\text { liver }\end{array}$ & $\begin{array}{c}\text { Percentage of viable } \\
\text { hepatocytes }\end{array}$ \\
\hline 1 & $5,05 \pm 0,05 \mathrm{n}=5$ & $(0,85 \pm 0,02) \times 10^{7}$ & 45 \\
\hline 2 & $6,94 \pm 0,05 \mathrm{n}=5$ & $(0,67 \pm 0,02) \times 10^{7}$ & 35 \\
\hline 3 & $9,7 \pm 0,15 \mathrm{n}=5$ & $(0,45 \pm 0,01) \times 10^{7}$ & 24 \\
\hline 4 & $13,2 \pm 1,0 \mathrm{n}=5$ & $(0,30 \pm 0,02) \times 10^{7}$ & 16 \\
\hline
\end{tabular}

Interesting data on clinical material was obtained by us. Liver biopsy was conducted on patients with various surgical diseases, as well as liver and biliary tract diseases. The biopsy material was analyzed in the same way as the experiment on laboratory gnawers (animals) Table 6 presents the values of the coefficient and the percentage of viable hepatocytes.

Table 6. Data on the coefficient and percentage of viable hepatocytes in animals with different models of hepatocellular damage and in patients with diseases of the hepatobiliary system

\begin{tabular}{|c|c|c|c|c|}
\hline \multirow{2}{*}{} & \multicolumn{2}{|c|}{ Experimental data (rats, dogs) } & $\begin{array}{l}\text { Clinical material } \\
\text { (surgical patients) }\end{array}$ \\
\cline { 2 - 5 } & $\begin{array}{c}\text { Coefficient } \\
\text { (in units) }\end{array}$ & $\begin{array}{c}\text { Percentage of viable } \\
\text { hepatocytes }\end{array}$ & $\begin{array}{c}\text { Coefficient } \\
\text { (in units) }\end{array}$ & $\begin{array}{c}\text { Percentage of viable } \\
\text { hepatocytes }\end{array}$ \\
\hline 1 & $1,9-2,0$ & $95-100$ & 2,5 & 95 \\
\hline 2 & $5-6$ & $43-45$ & $5-6$ & $40-45$ \\
\hline 3 & 7 & 35 & 8 & 35 \\
\hline 4 & 8 & 30 & - & -30 \\
\hline 5 & $10-11$ & $24-25$ & & \\
\hline 6 & $13-14$ & $15-16$ & & \\
\hline
\end{tabular}

The maximum value of the ratio of cytochrome C / TMPD-oxidase activities was 8.0 units, the minimum is 2.5 units. Its level is 2.5-3.0 units. occurred in planned patients admitted for surgical treatment of chronic uncomplicated cholecystitis, ulcer $12 p$ / c. A high level of coefficient occurred in patients with hepatolienal syndrome, cirrhosis of the liver, intrahepatic portal hypertension, and mechanical jaundice.

The data in this table also indicate that in the experiment in laboratory animals and in the clinic in patients we obtained almost identical values of the percentage of viable parenchyma and the corresponding coefficient values. This suggests that the ratio of cytochrome $\mathrm{C}$ to TMPD oxidase activity in gnawers (animal) cells is a constant, which seems to change in the same type and the basis of the change is the same biochemical processes.

\section{Conclusion:}

1. Damage to the liver during inoculation with hepatotropic poisons and obstructive jaundice leads to inhibition of cytochrome oxidase.

2. The ratio of cytochrome-C / TMPD-oxidase activities is an indicator of the destruction of the inner mitochondrial membrane and the impairment of hepatocyte bioenergetics.

3. The level of the coefficient corresponds to a certain amount of damaged / or intact / liver parenchyma.

4. In the experiment on gnawers (animals) and in the clinic with diseases of the organs of the hepatobiliary zone, the identity of the results of the coefficient level and the percentage of the intact liver parenchyma was obtained.

5. The use of the coefficient allows to predict the outcome of the disease, to objectively choose the method of surgical and conservative treatment, to monitor the postoperative period. 


\begin{tabular}{|c|c|c|c|c|c|c|}
\hline \multirow{4}{*}{ Impact Factor: } & ISRA (India) & $=3.117$ & SIS (USA) & $=0.912$ & ICV (Poland) & $=6.630$ \\
\hline & ISI (Dubai, UAE & $=0.829$ & РИНЦ (Russia & $=0.156$ & PIF (India) & $=1.940$ \\
\hline & GIF (Australia) & $=0.564$ & ESJI (KZ) & $=8.716$ & IBI (India) & $=4.260$ \\
\hline & JIF & $=1.500$ & SJIF (Morocco & $=\mathbf{5 . 6 6 7}$ & OAJI (USA) & $=0.350$ \\
\hline
\end{tabular}

\section{References:}

1. Buechter, H., Zepp, R., \& Gomer, G. (1990). The use of segmental anatomy for an operative classification of Liver injuries. Ann.Surg., Vol.211, №6: 669-675.

2. Dunaevsky, O. A. (1985). Differential diagnosis of liver diseases. (p.262). Moscow: Medicine.

3. Giuliano, F., et al. (1987). Les traumatisms du foie. J.Chir., Vol.124, №2:12-15.

4. Khazanov, A. I. (1988). Functional diagnosis of liver disease. (p.302). Moscow: Medicine.

5. Masevich, S. T., \& Ermolaeva, L. G. (2002). Clinical, biochemical, morphological features of chronic hepatitis of various etiology. Therapeutic archive, №2: 35-37.

6. Navruzbekov, M. S. (2009). Estimation of the functional reserves of the liver and methods for predicting liver failure in liver operations. Abstract of dissertation of PhD. (p.34). Moscow.

7. Ozawa, K. (1980). Adaptive response to hepatic functional reserve. Evolution by cytochrome a (+a 3) assay and glucose intolerance. Asian Med J, 23 No. 7: 499-528, 126-134.

8. Podymova, S. D. (1998). Liver Diseases: A Guide for Doctors. (p.704). Moscow: Medicine.

9. Sakhipov, S. Z. (1983). Violation of the functional state and microcirculation of the liver with mechanical jaundice. The dissertation of the candidate medical sciences. (p.162). Moscow.

10. Titov, V. N. (1993). Biochemical methods for diagnosing liver pathology. Therapeutic archive, №2: 85-89. 